\title{
Питання психології
}

УДК 159.9.019.4:37.013.77-053.6

DOI: $10.33099 / 2617-6858-20-56-3-81-87$

Марценюк М. О. кандидат психологічних наук, стариий викладач кафедри психологї Мукачівський держсавний університет https://orcid.org/0000-0002-2485-9624

\section{ЗДОРОВА ПОВЕДІНКА ТА Ї̈̈ ПОРУШЕННЯ В СВТТОСПРИЙМАННІ СУЧАСНОЇ МОЛОДІ}

\begin{abstract}
Стаття присвячена вивченню уявлень сучасної молоді щзодо здорової поведінки та порушень, а також їх місия в світосприйманні молоді. Розглянуто поняття «здоров 'я» з погляду різних вчених та дослідників минулого і сучасності. Досліджено та розкрито позицію иінності здоров'я та ЗСЖ. Проаналізовано результати емпіричного дослідження із застосування кореляџійного аналізу та висвітлені основні тендениії та причини порушень здорової поведінки у сучасному молодіжному середовищі.
\end{abstract}

Ключові слова: здоров'я; здоровий спосіб життя; молодіжне середовище; здорова поведінка; нездорова поведінка.

Постановка проблеми. Значення здоров'я в житті кожної людини та суспільства набуває сьогодні все більшої ваги. Центр профілактичних зусиль сьогодні змішується із конкретних розладів на загальне зміцнення здоров'я. Все більшого значення набувають дослідження здоров'я в контексті гуманітарних дисциплін, особливо соціальної психології, яка займається дослідженням механізмів, що орієнтують на здоровий спосіб життя, пропагандою превентивної поведінки [7].

Показники здоров'я розглядаються у сучасному соціумі, як кумулятивні індикатори рівня благополуччя суспільства в цілому та окремих його прошарків. Численні дослідження показують, що стан здоров'я людей в Україні постійно знижується, тому збереження та зміцнення здоров'я людини $\epsilon$ актуальною проблемою і турботою нашої держави. Здоров 'я людини $\epsilon$ досить складним феноменом та може розглядатися як філософська, соціальнаекономічна, біологічна, медична, соціальнопсихологічна категорія, як об'єкт споживання, внесення капіталу, як індивідуальна і суспільна цінність, явище системного характеру, динамічне, постійно взаємодіюче з оточуючим середовищем, що, у свою чергу, також постійно змінюється [1].

Аналіз останніх досліджень i публікацій. Проблема здоров'я особистості привертає увагу багатьох дослідників. Так, серед вітчизняних та зарубіжних дослідників питання, пов'язані із різними аспектами психічного здоров'я, розглядали:

О. В. Алексєєв (настрій і здоров'я); М.Й. Боришевський (психологія самоактивності та суб'єктного розвитку особистості як саморегульованої соціально-психологічної системи); Б.С. Братусь (аномалії особистості); І.В. Дубровіна (психологічне здоров'я учасників освітнього процесу); Л.Д. Дьоміна, I.О. Ральникова (психічне здоров'я та захисні механізми особистості); Г.В. Ложкін, М.I. Мушкевич, О. В. Наскова, І.В. Толкунова (психологія здоров'я людини); С.Д. Максименко (генетична психологія); Г. С. Нікіфоров (психологія здоров'я); В. М. Панкратов (саморегуляція психічного здоров'я); Д.Д. Федотов (збереження психічного здоров'я); О.В. Хухлаєва (особливості психічного здоров'я студентів); О.Я. Чебикін (проблема емоційної стійкості)та інші. Серед цілого ряду авторських позицій переважають наукові погляди, згідно 3 якими психологічне здоров'я розуміється як здатність особистості до самореалізації, самоактуалізації, адекватного самоприйняття себе та світу: В. Франкл, А. Маслоу (психологічне здоров'я як здатність особистості до самореалізації, самоактуалізації); А. Адлер, Е. Фромм (міжособистісні стосунки як важливий критерій психічного та психологічного здоров'я); а також дослідження С. Московичі, К. Ерзміш у яких проблема хвороби та здоров'я розглядається в руслі теорії соціальних уявлень та інші [4]. Рівень здоров'я людини визначається умовами життєдіяльності: навчання, праці та побуту, добробутом та гігієнічною культурою, а 


\section{Питання психології}

найбільше - способом життя. Спосіб життя включає в себе такі категорії, як рівень життя, якість його та стиль. Урахування важливості способу життя, поведінки у сфері здоров'я, як найважливіших детермінант здоров'я, не викликає сумніву [7].

Проблема формування здорового способу життя розкривається у соціальних дослідженнях Т. Бондар, О. Карпенко, П. Яременко, О. Балакірєвої, Е. Фоміна та інших; у психологічних дослідженнях $\mathrm{T}$. Титаренко, С. Максименка, М. Боришевського, М. Марценюк, Л. Лєпіхової, О. Кляпець та інших вітчизняних науковців. Як показує аналіз досліджень, проблема здоров'я людини, як фізичного так i психічного, збереження та підвищення їх рівня, а також урахування важливості способу життя, поведінки у сфері здоров'я, як найважливіших детермінант здоров'я, $\epsilon$ актуальною та потребує подальшого вивчення.

Мета статті. Наша робота має за мету визначити та окреслити уявлення сучасної молоді щодо здоров'я та здорової поведінки, а також емпірично дослідити основні причини іï порушень.

Методи дослідження. В процесі роботи були використані такі методи дослідження як: теоретичний аналіз, систематизація науково-теоретичних i методичних джерел, емпіричні методи (стандартизовані методики, спостереження, бесіди); методи обробки та інтерпретації даних (кількісні та якісні із застосуванням методів математичної статистики, а саме кореляційного аналізу за Пірсоном).

Виклад основного матеріалу. Здоров'я людини $є$ досить складним феноменом та може розглядатися як філософська, соціальна-економічна, біологічна, медична, соціально психологічна категорія, як об'єкт споживання, внесення капіталу, як індивідуальна i суспільна цінність, явище системного характеру, динамічне, постійно взаємодіюче 3 оточуючим середовищем, що, у свою чергу, постійно змінюється. У сучасних дослідженнях проблеми здоров'я виокремлюються біомедичний, соціальний та гуманітарний підходи. У сучасних гуманітарних уявленнях здоров'я представлене як «здоров'я для», що дає можливість говорити про ті можливості, які здоров'я надає людині. Здоров'я в рамках цього підходу $є$ одним 3 найважливіших ресурсів, які необхідні людині для того, щоб реалізовувати свій потенціал, свої можливості в усіх сферах життєдіяльності. Сьогодні здоров'я визначається як гармонійне поєднання фізіологічних, психологічних (особистісних, душевних) та соціальних факторів, які забезпечують внутрішне благополуччя індивіда. Фізичне здоров'я $\epsilon$ фундаментом загального здоров'я людини, та передбачає гарне самопочуття, бадьорість, наявність енергії, працездатність та відсутність патологічних симптомів [3].

На думку А. Маслоу, поняття «здоров 'я» можна трактувати як розвиток i рух у бік само актуалізації. Про самоактуалізованих особистостей можна говорити, що вони вже досягли достатнього рівня задоволення своїх базових потреб. А далі ними рухає мотивація більш високого порядку, що називається - метою мотивації. Ідеться про людей, які впевнені в собі, їхня потреба в любові задоволена, у них $\epsilon$ друзі, вони почувають себе улюбленцями й гідними любові, у них $\epsilon$ статус і місце в житті, вони користуються повагою інших та достатньою мірою відчувають власну цінність і самоповагу [4, C.64].

Основні положення, розроблені Г. Олпортом, складають основу гуманістичної ідеї здорової особистості. Як кожен персонолог, Г. Олпорт значну, але більш прискіпливу увагу присвятив розгляду поняття особистості, описавши i класифікувавши понад п'ятдесят різноманітних визначень. Це дало змогу досліднику виявити методологічну помилку сучасної йому психології: на його думку, майже відсутні визначення здорової особистості, а теорії особистості будуються на вивченні, як правило, нездорових або незрілих особистостей $[4$, C.69 $]$. Невід‘ємною частиною Олпортовської моделі здорової особистості $€$ критерії психологічної зрілості. х виділяють шість:

1) широкі межі - Я, активна участь у трудових, сімейних та соціальних взаєминах;

2) здатність до теплих, сердечних соціальних контактів (дружної інтимності та співчуття);

3) емоційна стійкість і самоприйняття; 


\section{Питання психології}

4) реалістичне сприймання людей, об“єктів, ситуацій, вибудовування реальних цілей, досвід та рівень домагань;

5) здатність до самопізнання і наявність почуття гумору (самооб'єктивність - чітке уявлення про свої сильні та слабкі сторони);

6) цілісна життєва філософія (домінуюча ціннісна орієнтація, яка складає об‘єднуючу основу життя).

Відповідно до аналізу праць автора, можна зробити висновок про те, що $Г$. Олпорт бачив особистісний ріст як безперервний процес становлення, який триває протягом життя i визначається пріоритетними цілями. [4, С.72].

Так, теорія здорової особистості А. Елліса передбачає різноспрямованість потенціалу, раціональність когніцій, відповідальне ставлення до життя. Дослідник Л.А. Руїс, обгрунтовуючи методологічні засади психології здоров'я, аналізує модель комплексного процесу «здоров'я-Хвороби» (ПЗХ). Він виділяе три рівні моделі ПЗХ:

1. Макросоціальний: взаємовідносини між суспільно-економічною формацією як єдиним цілим і станом здоров'я населення.

2. Груповий: відношення між способом i умовами життя певної групи населення (країни, міста).

3. Індивідуальний: відношення між індивідуальним стилем життя, умовами життя і станом здоров'я [4, С.81].

Д.Шульте пропонує для організації досліджень окремих проблем здоров'я використовувати «модель здоров'я», яка, за його словами, аналогічна до «моделі хвороби» і включає в себе 4 площини:

- передумови здоров'я (біологічні, соціальні, психологічні чинники, превентивні й саногенні фактори);

- власне здоров'я (відчуття щастя, задоволеність, відсутність дефекту);

- добре самопочуття (відсутність скарг i хворобливих симптомів);

- наслідки здоров'я (роль здорової людини і свобода поведінки).

У побудові даної моделі автор виходить 3 визначення здорової людини П. Беккера: здоровою $\epsilon$ працездатна людина, яка оптимально відповідає «нормальним» рольовим очікуванням і в змозі справитися зі щоденними вимогами, в результаті чого не має потреби приписувати ій особливу роль хворого. Фрейд 3. уважав психологічно здоровою людину ту, яка здатна узгодити принцип задоволення 3 принципом реальності. На думку К. Юнга, здоровою може бути особа, яка асимілювала зміст свого несвідомого й вільна від захоплення будь-яким архетипом. [4, С.82].

Молодь - це окрема (відносно велика) соціально-демографічна група, яка вирізняється за сукупністю вікових характеристик, особливостей соціального становища та обумовлених тим i іншим соціально-психологічних якостей, що визначаються суспільним ладом, культурою, закономірностями соціалізації, вихованням в умовах певного суспільства. Збереження й зміцнення здоров'я молодого покоління $\epsilon$ актуальною проблемою і турботою будьякої сім“ї, держави і справедливо вважається багатством нації, яка покладає надії у подальшому прогресивному розвитку на своїх нащадків $[5 ; 8 ; 9]$.

За даними медичних і психологічних спостережень (В. Г. Каменська, С. В. Звєрева, І. С. Мельникова), стосовно розвитку старшокласників наводяться тривожні показники стану їх здоров'я. Так, з початку 1990-х років ті чи інші захворювання, спричинені пережитими стресами, відмічались у 75 \% старшокласників, до кінця 90-х цей показник зріс серед випускників загальноосвітніх шкіл до 85 \%. Виявлено, що $\quad$ в $79 \%$ учнів відмічається стан емоційного напруження, а 85 \% учнів мають різні хронічні захворювання. У період, коли підлітки наближаються до старших класів, ï захворюваність на нервово-психічні та серцево-судинні розлади збільшується в півтора-два рази. Такий стан здоров'я молоді спеціалісти пояснюють складними соціально-економічними умовами пережитого десятиріччя 90-х років, що супроводжувалися суб“єктивним сприйняттям несприятливих наслідків соціальної нестабільності в суспільстві та, відповідно, в родинах, економічною кризою, втратою відчуття перспективи й неможливості обрати стійку систему цінностей. Відтак особистісна нестабільність спричинила серед молоді ускладнення самостійного й адекватного розв'язання проблем особистісного та професійного самовизначення [8].

У працях зарубіжних дослідників, присвячених вивченню уявлень про 


\section{Питання психології}

здоров'я i здорову людину в різних професійних і статеворольових групах, було виділено три складових уявлення про здоров'я:

1) адаптація, пристосування, що включає поняття норми, адекватності, працездатності, зовнішньої привабливості;

2) внутрішня згода (гармонія, упевненість, спокій, здоровий глузд);

3) самореалізація (активність, цілеспрямованість, творчість, тощо) [4].

У дослідженні І.Б. Бовіної методом асоціацій вивчалася структура уявлень про здоров'я i хворобу в молодіжному середовищі серед студентів ЗВО. Констатовано, що складовими ядра уявлень про здоров'я є: спорт, краса, сила, радість, бадьорість життя. Периферійну систему утворюють поняття: посмішка, гарний настрій, добре самопочуття, щастя, правильне харчування, веселощі, упевненість у собі, вітаміни, енергія, активність, свіже повітря. Здоров'я виявилося необхідною складовою успішності людини. При цьому І.Б. Бовіна доходить висновку, що ключовими елементами уявлення про здоров'я $\epsilon$ характеристики поведінки, пов'язані 3 підтримкою здоров'я, позитивних емоційних виявів і фізичного благополуччя [2].

У цілому молодь має правильне, адекватне уявлення про життєвий зміст понять «здоровий спосіб життя» i «нездоровий спосіб життя» 3 їх соціальнопсихологічними наслідками. ЗСЖ $\epsilon$ надійним потенціалом професійної ефективності, життєвого задоволення та успішності. Внаслідок нездорового способу життя людина потрапляє в ситуацію соціального обмеження, залежності від оточення, жалю і смутку. Все це $\epsilon$ знанням сучасної молоді про можливий спосіб життя та його наслідки. Проте в даному разі знання - це тільки фундамент, на якому може піднятися будівля, якість якої ініціюватиметься індивідуальним вибором кожного. Мотивація такого вибору не проста, як не $\epsilon$ простою і смислова будова свідомості. Згідно з ідеями Л.С. Виготського, смисли, вкорінені в буття, опредмечуються в діях та людській мові, а індивідуальна свідомість не зводиться лише до знання i, як відношення до світу, психологічно розкривається системою смислів, що є продуктом розвитку мотивів діяльності [7].

Здоровий спосіб життя далеко не завжди позитивно оцінюється в молодіжному середовищі. Цьому перешкоджають перш за все вікові особливості молодої людини. Піклуватися про власне здоров'я, як вважає велика частка молоді, це справа людей похилого віку чи інвалідів, а нормальні юнаки та дівчата мають великий ресурс, який дає їм змогу хронічно перевантажуватися, ризикувати, не помічати власних шкідливих звичок заради швидких заробітків, кар'єрного просування, досягнення матеріальної незалежності від батьків тощо. Типовою причиною формування негативного ставлення молоді до власного здоров'я $\epsilon$ гостре переживання кризових життєвих ситуацій. Якщо все так погано, якщо мене не кохають, якщо я не вступив до 3ВО, мене не взяли на роботу, то про яке здоров'я йдеться? Індивідуальні стратегії опанування нерідко далекі від конструктивних, самозберігаючих. Зорієнтованість молоді на нездоровий спосіб життя є одним 3 показників загальної життєвої некомпетентності, адже наявність таких орієнтацій суттєво знижує ймовірність професійного зростання, швидкого кар'єрного просування, досягнення життєвого успіху [9].

Для кращого розкриття теми статті було проведено емпіричне дослідження. Для дослідження було використано наступні методики [6; 10]:

1. Опитувальник порушень здорової поведінки О.Л. Луценко й О.Є. Габелкової.

2. Тест-опитувальник А.В. Звєрькова i Е.В. Ейдмана «Дослідження вольової саморегуляції»;

3. Опитувальник Міні-мульт (скорочений багатофакторний опитувальник для дослідження особистості);

4. Опитувальник ПлутчикаКеллермана-Конте «Індекс життєвого стилю».

Результати даного дослідження були оброблені за допомогою кореляційного аналізу за Пірсоном. Проведений нами кореляційний аналіз показав, що значимо корелюють між собою шкали, як от: Емоційна некомпетентність та Істерія (r $=0,505) ;$ Емоційна некомпетентність та Психастенія ( $\mathrm{r}=0,537)$; Наполегливість та 


\section{Питання психології}

Самовладання (r =0,617); Наполегливість та Гіперкомпенсація $(\mathrm{r}=0,521)$; Іпохондрія та Депресія $(\mathrm{r}=0,663)$; Іпохондрія та Істерія $(\mathrm{r}$ $=0,803)$; Іпохондрія та Психастенія (r $=0,687)$; Іпохондрія та Шизоїдність $(\mathrm{r}$ $=0,622)$; Депресія та Істерія ( $\mathrm{r}=0,671)$; Депресія та Психопатія $(\mathrm{r}=0,570)$; Депресія та Паранойяльність $(\mathrm{r}=0,649)$; Депресія та Психастенія (r =0,677); Депресія та Шизоїдність $(\mathrm{r}=0,572)$; Істерія та Психопатія $(\mathrm{r}=0,503)$; Істерія та Психастенія $(\mathrm{r}=0,604)$; Істерія та Шизоїдність $(\mathrm{r}=0,506)$; Психопатія та Психастенія ( $\mathrm{r}=0,531)$; Психопатія та Шизоїдність ( $\mathrm{r}=0,624)$; Паранойяльність та Психастенія $(\mathrm{r}=0,533)$; Паранойяльність та Шизоїдність $(\mathrm{r}=0,676)$; Паранойяльність та Регресія ( $\mathrm{r}=0,508)$; Психастенія та Шизоїдність ( $\mathrm{r}=0,722)$; Регресія та Проекція $(\mathrm{r}=0,528)$; Регресія та Гіперкомпенсація $(\mathrm{r}=0,576)$; Проекція та Гіперкомпенсація $(\mathrm{r}=0,587) .184$ Це може виступати свідченням про схильність молодої людини до егоцентризму, імпульсивності, емоційної незрілості, емоційної некомпетентності, пасивності, поганого пристосування, труднощах в міжособистісному спілкування, конфліктності, схильності до депресивних переживань, а також, того, що вона ще не стикалася з проблемами зі здоров'ям, і тому може досить легковажно до нього ставитися, не задумуватися про наслідки, поводитися так як модно, нехтувати власною безпекою.

Відзначимо, що обернено корелюють між собою шкали: Наполегливість та Депресія, де наявний помірний, обернений зв'язок ( $\mathrm{r}=-0,483)$, Наполегливість та Психастенія $(\mathrm{r}=-0,429)$, Наполегливість та Регресія $(\mathrm{r}=-0,462)$, Наполегливість та Гіперкомпенсація $(\mathrm{r}=-0,521)$, що свідчить про наявність у наполегливих людей захисного механізму - гіперкомпенсації, Самовладання та Регресія $(\mathrm{r}=-0,444)$, що вказує на те, що чим більше людина контролює свої почуття та поведінку, тим більше вона прагне уникати тривогу шляхом переходу на більш ранні стадії розвитку, тобто для неї може бути притаманною регресивна поведінка як захисний механізм психіки.

Такі результати можуть свідчити про недосвідченість в побудові міжособистісних стосунків, боязні невдач, надання переваги стратегії уникнення над стратегією долання перешкод, браку особистого життєвого досвіду та досвіду в соціальних контактах.

Висновки і перспективи подальших досліджень. Підсумовуючи вищевикладене, можна справедливо зазначити, що здоров'я - це стан повного фізичного, психічного i соціального благополуччя, a не лише відсутність хворобливих змін. Це досить узагальнене визначення скоріше характеризує те, до чого слід прагнути, бачити бажане дійсним. Здоров'я - це, насамперед, стан організму, в якому поєднуються відповідність структури i функції, а також властивість регулюючих систем підтримувати постійність внутрішнього середовища (гомеостаз). Здоров'я полягає в тому, що у відповідь на дію щоденних подразників виникають адекватні реакції, які за характером, силою, часом і тривалістю дії властиві більшості людей. Поняття «здоров'я» розглядалося представниками різних психологічних концепцій. I кожен з них тлумачив поняття «здоров'я» 3 своєї точки зору. Вивчаючи позицію цінності здоров'я та ЗСЖ в світосприйманні молоді та ставлення молоді до здорової поведінки можна стверджувати, що у цілому молодь відзначає здоров'я в переліку своїх пріоритетів, має правильне, адекватне уявлення про життєвий зміст понять «здоровий спосіб життя» i «нездоровий спосіб життя» 3 їх соціальнопсихологічними наслідками. Для них ЗСЖ є надійним потенціалом професійної ефективності, життєвого задоволення та успішності. Внаслідок нездорового способу життя людина потрапляє в ситуацію соціального обмеження, залежності від оточення, жалю і смутку. Все це $є$ знанням сучасної молоді про можливий спосіб життя та його наслідки. Проте в даному разі знання - це тільки фундамент, на якому може піднятися будівля, якість якої ініціюватиметься суб'єктним, індивідуальним вибором кожного. Перспективу подальших розробок вбачаємо у психологічних розробках просвітницьких тренінгів для підлітків та молоді 3 метою пропагандування ЗСЖ та формування ціннісного ставлення до нього. 


\section{Питання психології}

\section{Список використаних джерел}

1. Амосов М.М. Роздуми про здоров'я / М.М. Амосов. - К.: Здоров'я, 1990. -258 с.

2. Бовина И.Б. Представление о здоровье и болезни в молодежной бреде / И.Б. Бовина // Вопросы психологии. -2005 . - № 3. - С. $90-96$.

3. Васильева О.С. Психология здоровья человека: эталоны, представления, установки: учеб. пособие для студ. вузов / О.С.Васильева, Ф. Р.Филатов. - М.: Академия, 2014. - 352 с.

4. Коцан I.Я. Психологія здоров'я людини/ Коцан І.Я., Ложкін Г.В., Мушкевич М.I. - Луцьк: PBВ: «Вежа» Волин. нац. ун-ту ім. Лесі Українки, 2011.- 430 с.

5. Марценюк М.О. Психологічні особливості розвитку ціннісного ставлення до здорового способу життя: дис... канд. психол. наук: 19.00.01/ М.О. Марценюк. - Ін-т психології ім. Г. С. Костюка НАПН України, 2014.- 198 с.

6. Марценюк М.О. Дослідження причин порушень здорової поведінки у молодіжному середровищі / М.О.Марценюк, В.В.Штима//Наука майбутнього: збірник наукових праць студентів, аспірантів та молодих вчених / гол. ред. колегії В.В. Гоблик; заст. гол. ред. І.І. Алмашій. - Мукачево: РВВ МДУ, 2019. - Вип. 1(3). -257 с.

7. Психологічне здоров'я людини в контексті здорового способу життя [Електронний ресурс] / Коробка Л. - Режим доступу: http://socialscience.com.ua/article/489

8. Сірко Р.І. Психічне здоров'я у старшому юнацькому віці як предмет психологічного аналізу: дис. ... канд. психол. наук: 19.00.01. / Р.І. Сірко. - К.: Інститут психології імені Г.С. Костюка НАПН України, 2002. $-154 \mathrm{c}$.

9. Титаренко Т.М. Формування в молоді настанов на здоровий спосіб життя /Титаренко Т.М., Лєпіхова Л.А., Кляпець О.Я. - Київ, 2006. - 123 с.

10. Энциклопедия психодиагностики. Психодиагностика взрослых / редактор-составитель Д.Я. Райгородский. - Самара: Издательский Дом "Бахрах - M", 2009. - 704 с.

\section{References}

1.Amosov M.M., (1990). Rozdumy pro zdorov'ia [Reflections on health] - K.: Zdorov'ia (in Ukrainian).

2. Bovyna Y.B., (2005). Predstavlenye o zdorove y bolezny v molodezhnoi brede [Representations of health and diseases in youthen vironment] Voprosy psykholohyy, № 3. 90 - 96 (in Russian).

3. Vasyleva O.S., Fylatov F.R., (2014). Psykholohyia zdorovia cheloveka: etalony, predstavlenyia, ustanovky [Psychology of person's health: templates, presentations and installations] / O.S.Vasyleva, F. R.Fylatov. - M.: Akademyia (in Russian).

4. Kotsan I.Ia., Lozhkin H.V., Mushkevych M.I. (2011). Psykholohiia zdorov'ia liudyny [Psychology of human health]. Lutsk: RVV: «Vezha» Volynskogo natsionalnogo universitetu im. Lesi Ukrainky (in Ukrainian).

5. Martseniuk M.O. (2014). Psykholohichni osoblyvosti rozvytku tsinnisnoho stavlennia do zdorovoho sposobu zhyttia[Psychological features of the development of values to a healthy lifestyle]: dys. kand. psykhol. nauk: 19.00.01/K. Instytyt psykholohii im. H. S. Kostiuka NAPN Ukrainy (in Ukrainian).

6. Martseniuk M.O., Shtyma V.V., (2019). Doslidzhennia prychyn porushen zdorovoi povedinky u molodizhnomu seredrovyshchi [Research of the reasons of disturbances of healthy behavior in the youth environment]/ Nauka maibutnoho: zbirnyk naukovykh prats studentiv, aspirantiv ta molodykh vchenykh / hol. red. kolehii V.V. Hoblyk; zast. hol. red. I.I. Almashii. - Mukachevo: RVV MDU (in Ukrainian).

7. Korobka L., (2011). Psykholohichne zdorovia liudyny v konteksti zdorovoho sposobu zhyttia [Psychological human healthin the context of a healthy lifestyle]. [Elektronnyi resurs]. Rezhym dostupu: http://socialscience.com.ua/article/489 (in Ukrainian).

8. Sirko R.I. (2002). Psykhichne zdorov'ia u starshomu yunatskomu vitsi yak predmet psykholohichnoho analizu[Mental health in adolescence as a subject of psychological analysis]: dys. ... kand. psykhol. nauk: 19.00.01. /K.: Instytut psykholohii imeni H.S. Kostiuka NAPN Ukrainy (in Ukrainian)..

9. Tytarenko T.M., Liepikhova L.A., Kliapets O.I. Formuvannia v molodi nastanov na zdorovyi sposib zhyttia [Formation of youth guidelines for a healthy lifestyle]. Kyiv, 2006. - 123 p. (in Ukrainian).

10. Entsyklopedyia psykhodyahnostyky. Psykhodyahnostyka vzroslikh (2009). [Encyclopedia of psychodiagnostics. Psychodiagnostics of adults]/ redaktor-sostavytel D.Ia. Raihorodskyi. - Samara: Yzdatelskyi Dom "Bakhrakh - «M» (in Russian).

\section{Резюме \\ Марценюк М. кандидат психологических наук, стариий преподаватель кафедри психологии Мукачевский государственный университет \\ ЗДОРОВОЕ ПОВЕДЕНИЕ И ЕГО НАРУШЕНИЯ В МИРОВОСПРИЯТИИ СОВРЕМЕННОЙ МОЛОДЕЖИ}

Статья посвящена изучению представлений современной молодежи относительно здорового поведения и нарушений, а также их места в мировосприятии молодежи. Рассмотрено понятие «здоровье» с точки зрения разньх ученых и исследователей прошлого и современности. Исследовано и раскрыта позиция ченности здоровья и ЗСЖ. Проанализированы результать эмпирического 


\section{Питання психології}

исследования из применения коррелящ̧ионного анализа и освещеены основнае тенденции и причины нарушений здорового поведения в современной молодежной среде.

Ключевые слова: здоровье; здоровый образ жизни; молодежная среда; здоровое поведение; нездоровое поведение.

\section{Summary}

Martsenyuk $\boldsymbol{M}$. candidate of psychological science, senior lecturer, Department of psychology

Mukachevo state university

\section{HEALTHY BEHAVIOR AND ITS VIOLATION IN THE WORLD PERCEPTION OF MODERN YOUTH}

Introduction. The article deals with the topical issue of modernity - an idea of modern youth as to the healthy behavior and its violation, also its place in youth'sperception. It is emphasized that the problem of healthy person as physical so psychological, preservation and enhancement of its leveltaking into account the importance of lifestyle, health behavior as the main importantdeterminant of health is relevant and further study has been needed. The notion "health" from the point of view of different scientists and investigators of past and present has been considered. As research analysis shows the problem of person's health as physical so psychological,preservation and enhancement of its leveltaking into account the importance of lifestyle, health behavior as the main important determinant of healthis relevant and the further study has been needed.

The position of the value of health and healthy lifestylein the worldview of youth and their attitude to healthy behavior and its violation has been researched and disclosed. It has also been indicated that healthy lifestyle isn't always evaluated in youth environment and the problem is with age peculiarities of young person. As young people consider, care of one's own health - is the case of the elderly or disabled but they have great resource which gives them the ability to reboot, risk and not notice their own bad habitsfor the sake of quick earnings, career advancement, achieving material independence from parentsetc. A typical reason for the formation of negative attitudes of young peopleto their health is acute experienceof crisis life situations.

The results of empirical research with the use of correlative analysis and main tendencies and reasons for disorders of healthy behavior in modern youth environment have been analyzed and highlighted. The conclusions have been made that, in general, young people mention health in their list of priorities, have correct and adequate representationabout vital meaning of the concepts "healthy lifestyle" and "unhealthy lifestyle". However, they can be careless to their own health and not think about the consequences, behave as it is fashionable and neglect their own safety as they consider that care about own health is the case of the elderly or disabled.

Purpose. Our aim is to identify and outline the ideas of modern youth of health and healthy behavior, also to investigateempirically the root causes of its violations.

Methods. In the process of work there have been used such methods of investigation as: theoretical analysis, systematization of scientific-theoretical and methodological sources, empirical methods (standardized methods, observations, conversations); methods of data processing and interpretation (quantitative and qualitative methods of mathematical statistics, namely Pearson correlation analysis).

Originality. The scientific novelty of the article isresearch and coverage of the position of modern boys and girlsregarding the value of health and healthy lifestyle in worldview of youth and their attitude to healthy behavior. According to the obtained results, it is possible to affirm that in general, youth define health in the list of their priorities and have correct, adequate representation about vital meaning of concepts "healthy lifestyle" and "unhealthy lifestyle" with their socio-psychological consequences.

Conclusion. The perspective of further development can be seen in psychological development of educational trainings for teenagers and youthin order to promote healthy lifestyle and form a value attitude towards it.

Key words: health; healthy lifestyle; youth environment; healthy behavior; unhealthy behavior. 